\title{
Non-invasive assessment of porcine oocyte quality by supravital staining of cumulus-oocyte complexes with lissamine green B
}

\author{
Rahul Dutta ${ }^{1}$,Shun Li $i^{2,3}$, Konrad Fischer ${ }^{2}$,Alexander Kind ${ }^{2}$,Tatiana Flisikowska ${ }^{2}$, \\ Krzysztof Flisikowski ${ }^{2}$, Oswald Rottmann ${ }^{2}$ and Angelika Schnieke \\ Chair of Livestock Biotechnology, Technische Universität München, Freising, Germany
}

Date submitted: 18.03.2015. Date revised: 26.05.2015. Date accepted: 05.06.2015

\section{Summary}

We evaluated the usefulness of lissamine green B (LB) staining of cumulus-oocyte complexes (COC) as a non-invasive method of predicting maturational and developmental competence of slaughterhousederived porcine oocytes cultured in vitro. Cumulus cells of freshly aspirated COCs were evaluated either morphologically on the basis of thickness of cumulus cell layers, or stained with LB, which penetrates only non-viable cells. The extent of cumulus cell staining was taken as an inverse indicator of membrane integrity. The two methods of COC grading were then examined as predictors of nuclear maturation and development after parthenogenetic activation. In both cases LB staining proved a more reliable indicator than morphological assessment $(P<0.05)$. The relationship between LB staining and cumulus cell apoptosis was also examined. Terminal deoxynucleotidyl transferase dUTP nick end labeling (TUNEL) assay for DNA fragmentation revealed that oocytes within COCs graded as low quality by either LB staining or visual morphology showed significantly greater DNA fragmentation $(P<0.05)$ than higher grades, and that LB and visual grading were of similar predictive value. Expression of the stress response gene TP53 showed significantly higher expression in COCs graded as low quality by LB staining. However expression of the apoptosis-associated genes $B A K$ and CASP3 was not significantly different between high or low grade COCs, suggesting that mRNA expression of $B A K$ and CASP3 is not a reliable method of detecting apoptosis in porcine COCs. Evaluation of cumulus cell membrane integrity by lissamine green B staining thus provides a useful new tool to gain information about the maturational and developmental competence of porcine oocytes.

Keywords: Cumulus cells, IVM, Lissamine green B, Membrane integrity, Pig, TP53, TUNEL

\section{Introduction}

Genome editing directly in mammalian embryos (Meyer et al., 2010; Flisikowska et al., 2013) is a powerful new technique that promises to radically streamline the genetic modification of large animal species, such as pigs, and so provide exciting new resources for biomedical research. However such an approach requires a reliable supply of development-

\footnotetext{
${ }^{1}$ All correspondence to: Rahul Dutta. Chair of Livestock Biotechnology, Technische Universität München, Freising, Germany. e-mail: doctordut@gmail.com

${ }^{2}$ Chair of Livestock Biotechnology, Technische Universität München, Freising, Germany.

${ }^{3}$ Present address: Shanghai Public Health Clinical Center, Jin Shan District, Shanghai 201508, China.
}

ally competent porcine embryos. The first successful birth of a piglet derived by in vitro fertilization (IVF) of porcine oocytes flushed from the reproductive tract was reported almost 3 decades ago (Cheng et al., 1986), and there have since been numerous reports of live births in pigs by IVF (Grupen, 2014), but obtaining in vivo matured oocytes is costly and time consuming (Nakai et al., 2003). Moreover, unlike cattle, non-surgical ovum pick up is not practical in pigs due to their anatomy. Developing in vitro production (IVP) of pig embryos including in vitro maturation (IVM) has however proved problematic, and the systems available are still unacceptably inefficient, especially compared with other livestock species such as cattle (Grupen, 2014). In vitro matured porcine oocytes have problems at several stages in the process. They have reduced ability to be fertilized in vitro, 
to block polyspermy, to undergo normal pronuclear formation upon sperm penetration (Abeydeera \& Day, 1997; Abeydeera, 2002) and culture conditions are suboptimal for supporting embryo development beyond the initial cleavage divisions (Grupen, 2014).

Pig ovaries are usually obtained from slaughterhouses, which is convenient, but variations between animals and their handling can significantly affect the quality of the tissue arriving in the laboratory. For example, porcine oocytes are highly susceptible to temperature stress, and transient temperature shocks can occur in vivo during slaughter (Tong et al., 2004), or ovaries be exposed to low temperature after removal (Yuge, 2003). These stresses result in poor maturation and subsequent embryo development and are often outside the control of the experimenter. A simple, reliable means of identifying cumulus-oocyte complexes (COC) with high maturational competence before IVM culture would reduce an important source of variability and aid the improvement and standardisation of subsequent IVM conditions.

As with many mammalian species, porcine COCs are usually graded by visual assessment of morphological features such as the thickness and compactness of the cumulus investment, ooplasm homogeneity (Akshey et al., 2011; Garg et al, 2012) and the size of follicles (Hyttel et al., 1997; Hendriksen et al., 2000) or oocytes (Coticchio et al., 2004). Based on light microscopy, mammalian COCs surrounded by several layers of cumulus cells and with evenly granulated ooplasm have higher developmental competence in vitro than oocytes with irregularly granulated ooplasm and fewer cumulus layers (Wang et al., 1997; Sirard et al., 2006; Miyano \& Manabe, 2007). Many other different selection criteria have also been reported (Galeati et al., 1991; Gandhi et al., 2001; Qian et al., 2003).

The cumulus layer is undoubtedly vital for oocyte development, for example it plays an important role in the distribution of cortical granules, and thus the ability to undergo sperm penetration (Cheng et al., 2013). However visual observation provides only limited information about its functional competence. Alternative methods of analysing cumulus cells are available, including evaluation of telomere length (Lee et al., 2001), cumulus cell apoptosis (Corn et al., 2005; Assou et al., 2010) and gene expression profiling using microarray analysis (Ruppert-Lingham et al., 2006), but are too time consuming and expensive for routine laboratory use. Propidium iodide staining has also been used as a non-invasive method of determining cumulus cell integrity (Uchikura et al., 2011), but this requires fluorescence microscopy, which may not be available for some researchers and may be potentially mutagenic.
Here we report the use of lissamine green B (LB) dye to visually assess the quality of COCs used for in vitro culture. LB is used in ophthalmology to evaluate ocular membrane integrity (Hamrah et al., 2011), but to our knowledge has never been used previously in reproductive technology. LB is a nontoxic synthetic organic acid dye that can be used as a supravital stain and, unlike propidium iodide, is directly visible, making staining rapid and simple. LB offers an efficient, objective, non-invasive and directly visible means of selecting good quality COCs and oocytes.

\section{Materials and methods}

\section{Chemicals, cell culture media and supplements}

Chemicals, reagents and culture media were purchased from Sigma Chemical Co., St. Louis, MO, USA unless otherwise indicated. Media were prepared fresh and sterilised by $0.2 \mu \mathrm{m}$ membrane filtration.

\section{Collection of oocytes}

Slaughterhouse ovaries were brought to the laboratory within $1 \mathrm{~h}$ of collection in a temperaturecontrolled box maintained at $39^{\circ} \mathrm{C}$. Ovaries were thoroughly washed with pre-warmed $\left(39^{\circ} \mathrm{C}\right)$ Dulbecco's phosphate-buffered saline (DPBS) solution containing $0.1 \%$ polyvinyl alcohol and penicillin, streptomycin solution. Follicles with a diameter of 3-8 $\mathrm{mm}$ were aspirated using an 18-gauge needle and a $5 \mathrm{ml}$ syringe. Aspiration medium consisted of HEPES-buffered TCM199 (M 2520) with $26 \mathrm{mM}$ $\mathrm{NaHCO}_{3}$ (S 5761), $1 \mathrm{mM}$ L-glutamine (G8540), 0. $5 \mathrm{mg} / \mathrm{ml}$ polyvinyl alcohol (P 8136), $50 \mu \mathrm{g} / \mathrm{ml}$ gentamicin (G1264) and $20 \mathrm{U} / \mathrm{ml}$ heparin (H3149). Oocytes (COCs) were retrieved in the same medium without heparin using a stereomicroscope. Oocytes with even, dark cytoplasm and more than one compact layer of cumulus cells were selected. In total, 767 oocytes (COCs) were obtained from $\sim 70$ ovaries. These were divided randomly into two groups, one to study nuclear maturation and one to study parthenogenetic activation. Each one was further divided randomly into two sub-groups, one was graded by the morphology of their surrounding cumulus investments: grade $\mathrm{A}$, at least three layers; grade $B$, less than three layers; or grade $C$, only corona radiata. The other sub-group was LB stained and scored according to a system previously used for propidium iodide staining (Ruppert-Lingham et al., 2006; Uchikura et al., 2011), with grade 1 having $<25 \%$ cumulus cells stained; grade $2,25-50 \%$ cumulus cells 


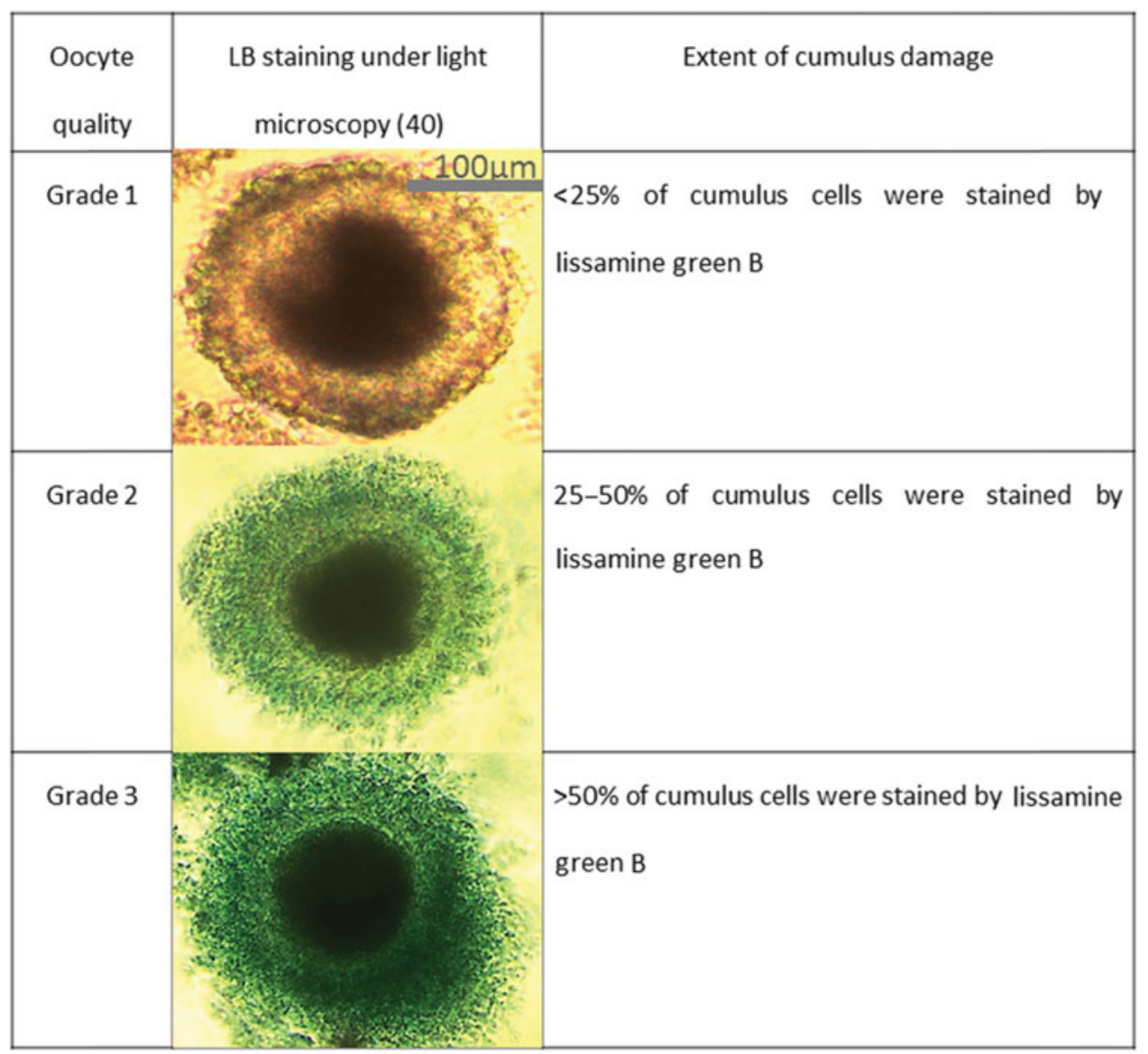

Figure 1 Classification of COCs by lissamine green B staining.

stained; and grade $3,>50 \%$ cumulus cells stained, as shown in Fig. 1.

\section{Optimization of lissamine green B staining}

A stock solution of 1\% LB (199583) in DPBS ( $\mathrm{pH}=$ 7.0) was prepared and further diluted into TCM199 medium. All staining was performed at $39^{\circ} \mathrm{C}$. Suitable staining conditions to detect cumulus cell damage were determined using COCs artificially damaged by treatment with $0.1 \%$ hyaluronidase (H3506) for $30 \mathrm{~min}$ at room temperature. Treated COCs were placed in groups of 25 in $500 \mu \mathrm{l}$ droplets at four different LB concentrations $(1,0.5,0.25$ or $0.1 \%)$ under mineral oil for $2.5,5$ or $10 \mathrm{~min}$. Each treatment was repeated three times. Following staining, COCs were washed in phosphate-buffered saline (PBS) to remove residual stain, observed by zoom stereomicroscope, and the number of stained COCs was recorded.

\section{Determination of nuclear maturation after IVM culture}

After quick assessment of cumulus membrane integrity, oocytes were washed twice in in vitro maturation
(IVM) medium and placed in groups of 40-60 in a final volume of $500 \mu \mathrm{l}$ IVM medium in 4-well dishes (Nunc $\mathrm{GmbH}$, Co. KG, Germany). Oocytes were cultured at $39^{\circ} \mathrm{C}$ under $5 \% \mathrm{CO}_{2}$ in air and maximum humidity for $46 \mathrm{~h}$. The maturation medium consisted of TCM 199 (M 2154) with $1 \mathrm{mM}$ L-glutamine, $1 \mathrm{mM}$ sodium pyruvate (P3662), $0.1 \mathrm{mM}$ 2-mercaptoethanol (M7522), $50 \mathrm{ng} / \mathrm{ml}$ epidermal growth factor (E4127), $50 \mu \mathrm{g} / \mathrm{ml}$ gentamicin and $0.1 \%(\mathrm{w} / \mathrm{v})$ BSA (A3311). During the first $24 \mathrm{~h}$ of IVM, the medium was supplemented with $10 \mathrm{IU} /$ $\mathrm{ml}$ PMSG and $5 \mathrm{IU} / \mathrm{ml}$ hCG (MSD Tiergesundheit, Germany) and $5 \mu \mathrm{l} / \mathrm{ml}$ ITS (recombinant human insulin, human transferrin, and sodium selenite, I3146) (Sjunnesson et al., 2013).

After IVM culture, cumulus investments were removed from the oocytes by gentle pipetting. Oocytes were then fixed for $30 \mathrm{~min}$ in $0.5 \%$ glutaraldehyde (500 $\mu \mathrm{l}$ PBS $+10 \mu \mathrm{l} 25 \%$ glutaraldehyde G-5882), washed in $500 \mu \mathrm{l}$ PBS for $5 \mathrm{~min}$ then transferred to 500 $\mu l$ Hoechst (B2261) stain solution (0.1\%). The nuclear status was evaluated using an epifluorescence microscopy (ultraviolet (UV) light filter; Carl Zeiss) using standard measures like germinal vesicle breakdown, condensation of chromatin and appearance of the 

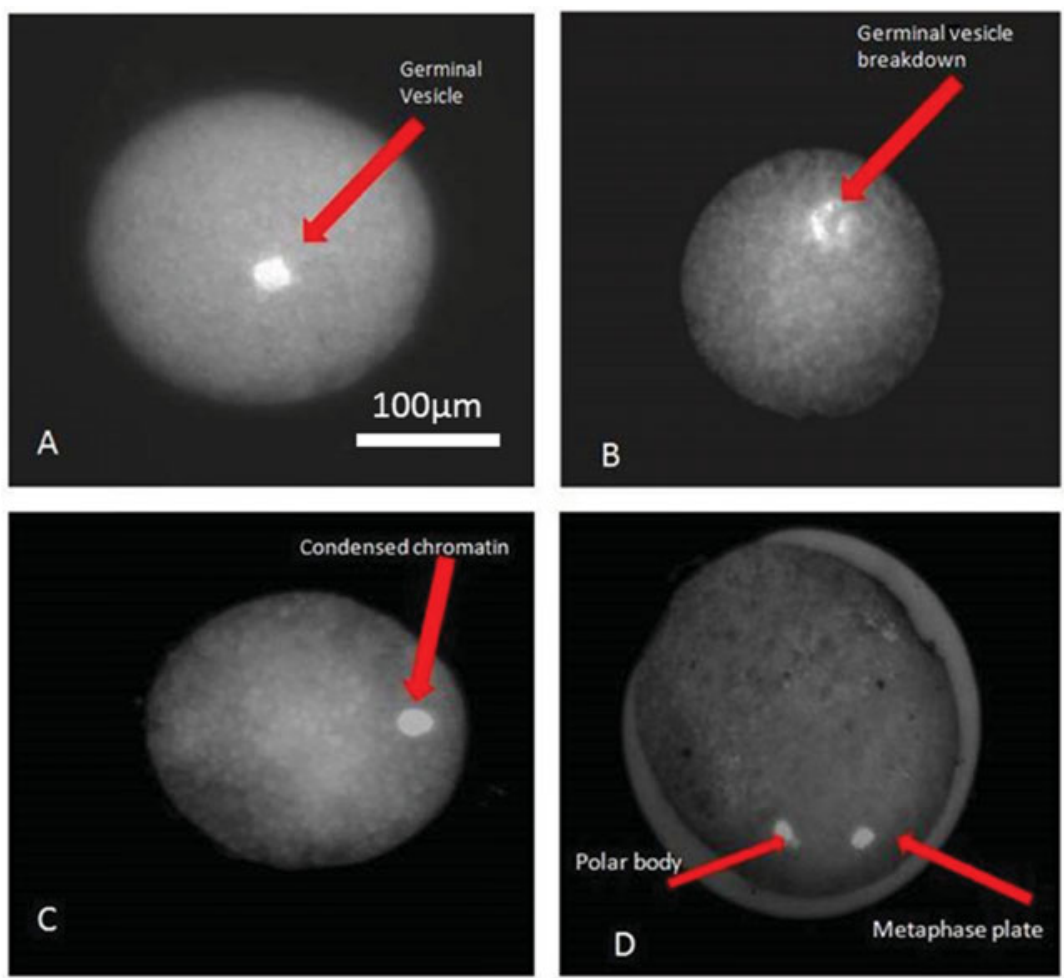

Figure 2 Progression of lissamine green B stained oocytes through different stages of maturation. $(A)$ Immature oocyte. $(B)$ Germinal vesicle breakdown. (C) Appearance of first polar body. (D) Mature oocyte with visible polar body and metaphase plate.

first polar body as confirmation of nuclear maturation (Fig. 2).

\section{Parthenogenetic activation of porcine oocytes}

Oocytes were activated chemically to assess their developmental competence. After $46 \mathrm{~h}$ IVM culture, COCs were manually denuded by mouth pipetting, then activated by incubating in IVM medium containing $5 \mu \mathrm{M}$ Ca-ionophore A23187 (C7522) for $5 \mathrm{~min}$ at $39^{\circ} \mathrm{C}$ under $5 \% \mathrm{CO}_{2}$ in air. Oocytes were washed three times in IVM culture medium and incubated in 500 $\mu l$ droplets containing $2 \mathrm{mM}$ 6-dimethylaminopurine (6-DMAP, D2629) and covered with mineral oil in an incubator at $39^{\circ} \mathrm{C}$ under $5 \% \mathrm{CO}_{2}$ in air for 4 h. After activation, oocytes were cultured in 500 $\mu l$ porcine zygote medium (PZM 5 IFP) in 4-well dishes (Nunc GmbH, Co. KG, Germany) overlaid with $500 \mu$ l mineral oil (M8410). The dish was incubated undisturbed at $39^{\circ} \mathrm{C}$ in $5 \% \mathrm{CO}_{2}$ in air for 7 days. Embryo development was observed microscopically and cleavage assessed at $48 \mathrm{~h}$ post-activation.

\section{RNA isolation and reverse-transcription}

Apoptotic gene expression was evaluated in groups of 50-60 COCs. Total RNA was isolated using an RNeasy Mini Kit (Qiagen, Europe) according to the manufacturer's instructions. Sample purity was assessed using the $A_{260} / A_{280} \mathrm{~nm}$ ratio with expected values between 1.8 and 2.0, RNA samples were treated with TURBO DNA-free ${ }^{\mathrm{TM}}$ Kit (Life Technologies) to remove genomic DNA. Reverse-transcription reactions were performed with $0.5-1 \mu \mathrm{g}$ total RNA using the SuperScript ${ }^{\circledR}$ III First-Strand Synthesis System for RT-PCR (Life Technologies) and random hexamer as a primer, according to the manufacturer's instructions. For each sample, negative controls lacking reverse transcriptase were prepared using the identical procedure.

\section{Quantitative real-time PCR}

Gene expression was assessed by quantitative RTPCR. Primers for BAK, CASP3 and TP53, and a housekeeping gene $A C T B$ (beta-actin) were designed using 'Primer3' software. The predicted fragment sizes are listed in Table 1. Real-time PCR amplification was conducted using an ABI 7300 real-time PCR System (Applied Biosystems). A KAPA SYBR FAST q PCR Kit (Kapa Biosystems) was used to provide realtime quantification of the amplified product. Three replicates of each reaction were measured and the mRNA level of each sample was normalised to that of 
Table 1 Primer sequences and annealing temperature

\begin{tabular}{|c|c|c|c|c|}
\hline Genes & Primer sequences & $\begin{array}{c}\text { Annealing } \\
\text { temperature }\left({ }^{\circ} \mathrm{C}\right)\end{array}$ & $\begin{array}{l}\text { Product } \\
\text { size (bp) }\end{array}$ & Accession no. \\
\hline$\beta$-Actin & $\begin{array}{l}\text { F-5'GTGGACATCAGGAAGGACCTCTA3'; } \\
\text { R-5'ATGATCTTGATCTTCATGGTGCT3' }\end{array}$ & 58 & 135 & U07786 \\
\hline Bak & $\begin{array}{l}\text { F-5'CAGCACCATGGGGCAGGTAG3'; } \\
\text { R-5'AGGCTGGAGGCGATCTTGGT3' }\end{array}$ & 58 & 150 & AJ001204.1 \\
\hline Caspase 3 & $\begin{array}{l}\text { F-5'GCCGAGGCACAGAATTGGAC3'; } \\
\text { R-5'GCGCTGCACAAAGTGACTGG3' }\end{array}$ & 58 & 180 & АВ029345.1 \\
\hline TP53 & $\begin{array}{l}\text { F-5'CTTTGAGGTGCGTGTTTGTG3'; } \\
\text { R-5'CGGATCTGGAGGGTGAAATA3' }\end{array}$ & 60 & 152 & AF098067.1 \\
\hline
\end{tabular}

beta-actin. Relative mRNA levels were determined by the $\Delta \Delta \mathrm{Ct}$ method (Livak \& Schmittgen, 2001).

\section{Measurement of DNA fragmentation}

The terminal deoxynucleotidyl transferase-mediated dUTP nick end labelling (TUNEL) procedure was used to fluorescein-dUTP label 3'-OH ends of DNA fragments generated by apoptosis, allowing detection of apoptotic cells by fluorescence microscopy. Fixed and permeabilized embryos were subjected to the TUNEL assay procedure using an in situ apoptosis detection kit (TaKaRa Bio Inc., Japan) according to the manufacturer's instructions. COCs were fixed for 30 min at room temperature in PBS ( $\mathrm{pH} 7.4)$, permeabilized for $5 \mathrm{~min}$ on ice in permeabilization buffer, and then washed once in PBS. COCs were incubated with terminal transferase and labelled nucleotide solution in a humidified, sealed chamber in the dark at $37^{\circ} \mathrm{C}$ for $1 \mathrm{~h}$. Slides were overlaid with a coverslip and the edges sealed with quick drying nail polish, then evaluated using an epifluorescence microscopy (green excitation filter, Carl Zeiss). Oocytes showing discrete pinpoint fluorescent green signals were judged to be positive for DNA fragmentation. The apoptosis score was expressed as a percentage of the total.

\section{Statistical analysis}

Data were analysed using GraphPad Prism (GraphPad Software, Inc. USA) after arcsin transformation of percentage values. Differences between mean percentages were analysed by two-way analysis of variance (ANOVA). A value of $P<0.05$ was considered to be statistically significant.

\section{Results}

\section{Lissamine B staining}

A staining regimen of $0.50 \% \mathrm{LB}$ for $5 \mathrm{~min}$ was found to be optimum for staining in terms of specificity and easily detectable coloration. Under light microscopy, damaged cumulus cells were stained greenish blue, while healthy cumulus cells remained unstained. The ooplasm of denuded oocytes that incurred damage to the zona pellucida stained greenish blue.

\section{Nuclear maturation}

Of the 372 COCs in the nuclear maturation group, 191 were graded by morphology, with 63 assessed as grade A $(32.99 \%), 67$ grade B $(35.07 \%)$ and 61 grade C (31.93\%); 181 were graded by LB staining as 59 grade 1 $(32.59 \%), 65$ grade $2(35.91 \%$, and 57 grade $3(31.49 \%)$. Nuclear maturation of each oocyte was scored by the attainment of metaphase II, as judged by the presence of condensed chromosomes in an equatorial position and extrusion of the first polar body (Fig. 2). Nuclear maturation data (Table 2) showed no significant difference between morphological grade A (79.9 \pm $3.82 \%)$, grade B $(86.48 \pm 3.07 \%)$, or grade C $(82.00 \pm$ $3.00 \%$ ) oocytes. The nuclear maturation rates of LB graded oocytes were: grade $1(84.70 \pm 3.36 \%)$, grade $2(83.61 \pm 3.44 \%)$ and grade $3(62.26 \pm 3.69 \%)$. The difference between grade 3 and grades 1 and 2 was significant $(P<0.05)$.

\section{Developmental competence of oocytes}

The parthenogenetic activation group comprised 395 oocytes. 204 were graded by morphology as 67 grade A $(32.84 \%), 71$ grade $B(34.80 \%)$ and 66 grade C $(32.35 \%) ; 191$ were graded by LB staining as 64 grade 1 $(33.50 \%), 65$ grade $2(34.03 \%)$, and 62 grade $3(32.46 \%)$. Development was scored as the number of embryos consisting of two to eight evenly sized blastomeres $48 \mathrm{~h}$ after parthenogenetic activation. There was no significant difference between morphological grade $\mathrm{A}$ $(84.55 \pm 4.45 \%)$, grade B $(85.06 \pm 4.49 \%)$, or grade C $(81.60 \pm 4.64 \%)$ oocytes. The rates of parthenogenetic activation in LB graded oocytes were: grade 1 (87.71 $\pm 2.46 \%)$, grade $2(82.72 \pm 3.39 \%)$ and grade $3(62.88$ $\pm 3.85 \%$ ). Again this shows a statistically significant 
Table 2 Effects of cumulus morphological categories on maturational and developmental ability of porcine oocytes

\begin{tabular}{|c|c|c|c|c|c|c|}
\hline \multirow[b]{3}{*}{ Item } & \multicolumn{6}{|c|}{ Nuclear maturation and parthenogenetic activation } \\
\hline & \multicolumn{3}{|c|}{ Grades based on cumulus investment } & \multicolumn{3}{|c|}{ Grades based on membrane integrity } \\
\hline & Grade A & Grade B & Grade C & Grade 1 & Grade 2 & Grade 3 \\
\hline Nuclear maturation (\%) & $79.9 \pm 3.8^{a}$ & $86.48 \pm 3.07^{a}$ & $82.00 \pm 3.00^{a}$ & $84.70 \pm 3.36^{a}$ & $83.61 \pm 3.44^{a}$ & $62.26 \pm 3.69^{b}$ \\
\hline Activation (\%) & $84.55 \pm 4.4^{a}$ & $85.06 \pm 4.49^{a}$ & $81.60 \pm 4.64^{a}$ & $87.71 \pm 2.46^{a}$ & $82.72 \pm 3.39^{a}$ & $62.88 \pm 3.85^{a}$ \\
\hline
\end{tabular}

Table 3 Rate of DNA fragmentations as detected by TUNEL assay in different category of porcine oocytes

\begin{tabular}{|c|c|c|c|c|c|c|}
\hline \multirow[b]{3}{*}{ Item } & \multicolumn{6}{|c|}{ DNA fragmentation assay } \\
\hline & \multicolumn{3}{|c|}{ Grades based on cumulus investment } & \multicolumn{3}{|c|}{ Grades based on membrane integrity } \\
\hline & Grade A & Grade B & Grade C & Grade 1 & Grade 2 & Grade 3 \\
\hline Apoptosis (\%) & $20.97 \pm 3.52^{a}$ & $22.69 \pm 4.05^{a}$ & $38.42 \pm 4.03^{b}$ & $21.66 \pm 4.08^{a}$ & $21.82 \pm 5.85^{a}$ & $37.08 \pm 2.76^{b}$ \\
\hline
\end{tabular}

difference between grade 3 and grades 1 and $2(P<$ 0.05) (Table 2).

\section{TUNEL assay for oocytes and cumulus cells}

In total, $176 \mathrm{COCs}$ were graded by either morphology or LB staining. For each grade a TUNEL score was determined as the percentage of observed COCs showing signs of DNA fragmentation, as indicated by a fluorescent signal (Table 3 and Fig. 3). Throughout, fluorescent signals were observed only in the ooplasm and not in the cumulus cells. There was no significant difference between morphological grade A (20.97 \pm $3.52 \%)$ and grade B (22.69 $\pm 4.05 \%)$ oocytes, but grade C oocytes showed significantly higher (38.42 \pm $4.03 \%)$ incidence of DNA fragmentation $(P<0.05)$. The TUNEL score in LB graded oocytes was similar: grade $1(21.66 \pm 4.08 \%)$, grade $2(21.82 \pm 5.85 \%)$, with grade 3 significantly higher $(37.08 \pm 2.76 \%)(P<0.05)$. There was no significant difference in TUNEL score between morphological grade $\mathrm{C}$ and LB grade 3 COCs.

\section{Expression of stress and apoptosis-related genes in lissamine B graded porcine COCs.}

Differential expression of the stress-associated gene TP53 and two genes related to apoptosis, $B A K$ (BCL2-antagonist/killer) and CASP3 (caspase 3), was analysed by quantitative real-time RT-PCR in three pools of 50-60 COCs representing LB-stained grades 1, 2 and 3 (Fig. 4). Three replicates were conducted for each experiment. Figure 4 shows that $B A K$ and CASP3 expression was similar in all grades of LBstained COCs, but TP53 expression was significantly greater $(P<0.05)$, in grade 3 COCs than grades 1 and 2.

\section{Discussion}

We evaluated the usefulness of lissamine green B (LB) staining for non-invasive prediction of maturational competence of porcine oocytes. LB preferentially stains membrane-damaged or devitalised cells (Kim \& Foulks, 1999). Studies using LB to stain rabbit and human corneal epithelial cells in vitro show that it does not stain healthy, proliferating cells and has a minimal effect on cell viability (Kim, 2000). Evidence to date indicates no carcinogenic or cytotoxic properties (Brantom et al., 1987; Clode, 1987; Moorhouse et al., 1987).

Our data indicate that LB staining of COCs immediately after collection is superior to morphological grading as a predictor of oocyte viability, nuclear maturation after IVM culture, and successful parthenogenetic activation and development. Parthenogenesis was used as a convenient and valid functional assay of developmental competence (Rougier \& Werb, 2001; McElroy et al., 2010).

While higher rates of nuclear maturation, fertilization and development after IVP have been reported in bovine oocytes graded on the basis of the thickness of the cumulus cell layers, our data show that this cannot automatically be extended to porcine oocytes. Our findings clearly reaffirm the importance of a cumulus layer for oocyte maturation and development (Davachi et al., 2012; Prates et al., 2014), but suggest 

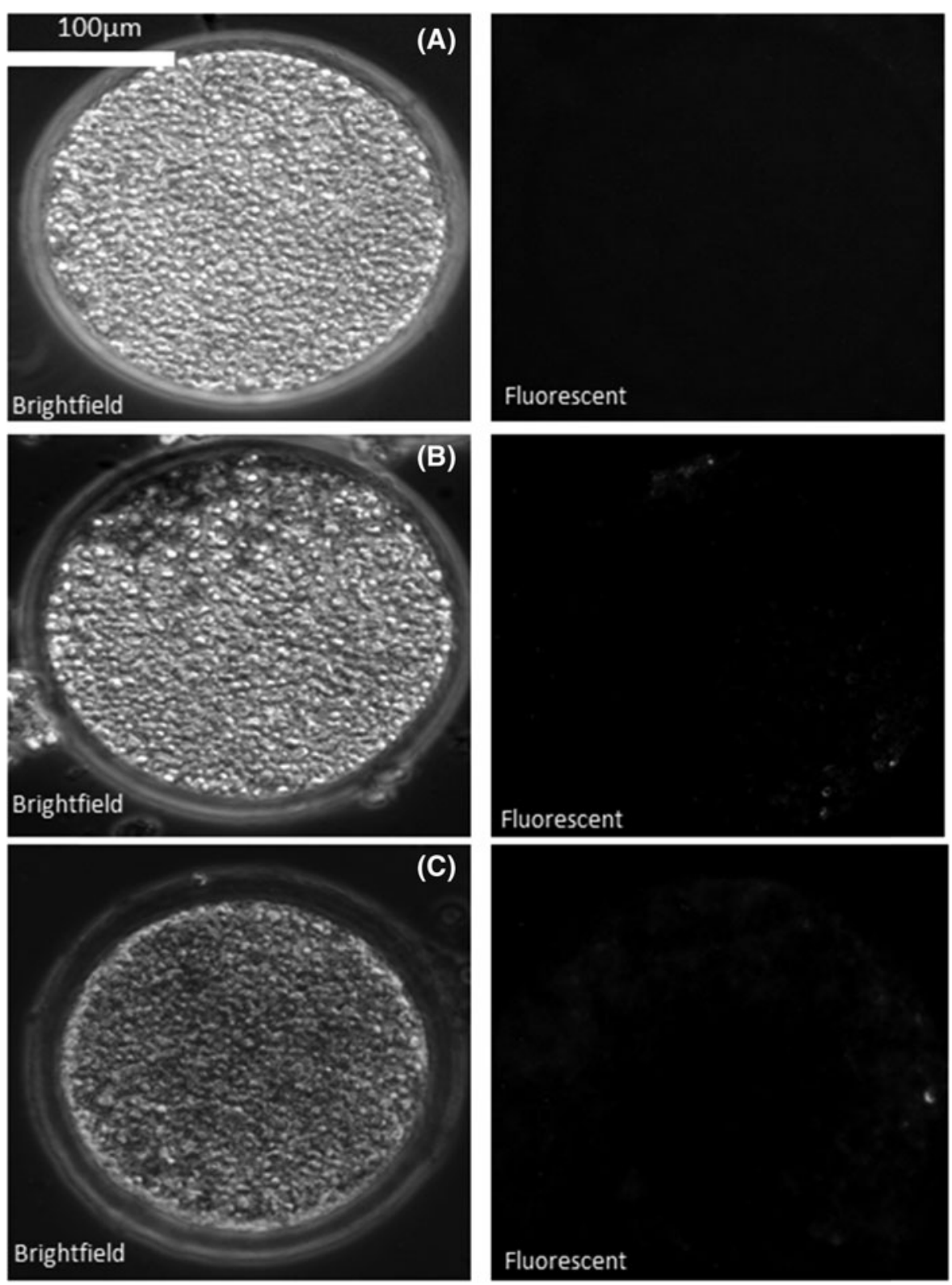

Figure 3 DNA fragmentation detection by TUNEL assay. (A) Porcine oocyte with no detectable DNA fragmentation. (B) Porcine oocyte with moderate DNA fragmentation. $(C)$ Porcine oocyte with extensive DNA fragmentation.

that measures of cumulus cell integrity are more useful than morphological parameters alone.

Our investigation of the role of apoptosis in COC quality revealed some interesting findings. As expected, DNA fragmentation measured by TUNEL assay showed that LB grade 3 COCs were more damaged than higher grade COCs, consistent with their developmental properties and also in line with morphological grade C COCs. DNA fragmentation in immature oocytes (in particular, GV and MI stages) could be a consequence of stress during maturation of the ovarian follicle or hypoxia resulting from compromised microcirculation and correlate with aneuploidy or other chromosomal abnormalities (Van Blerkom, 1996). It is notable that we found no evidence of DNA fragmentation in the cumulus layer in immature porcine COCs. This is consistent with a similar finding in cattle in which no TUNEL signal was obtained in cumulus cells of immature oocytes (Yuana et al., 2005).

Gene expression analysis of three genes chosen for their well known roles in stress and apoptosis however revealed an interesting and unexpected distinction. The expression of TP53, a stress response gene induced by DNA damage, was significantly greater in LB-stained grade 3 COCs, consistent with 

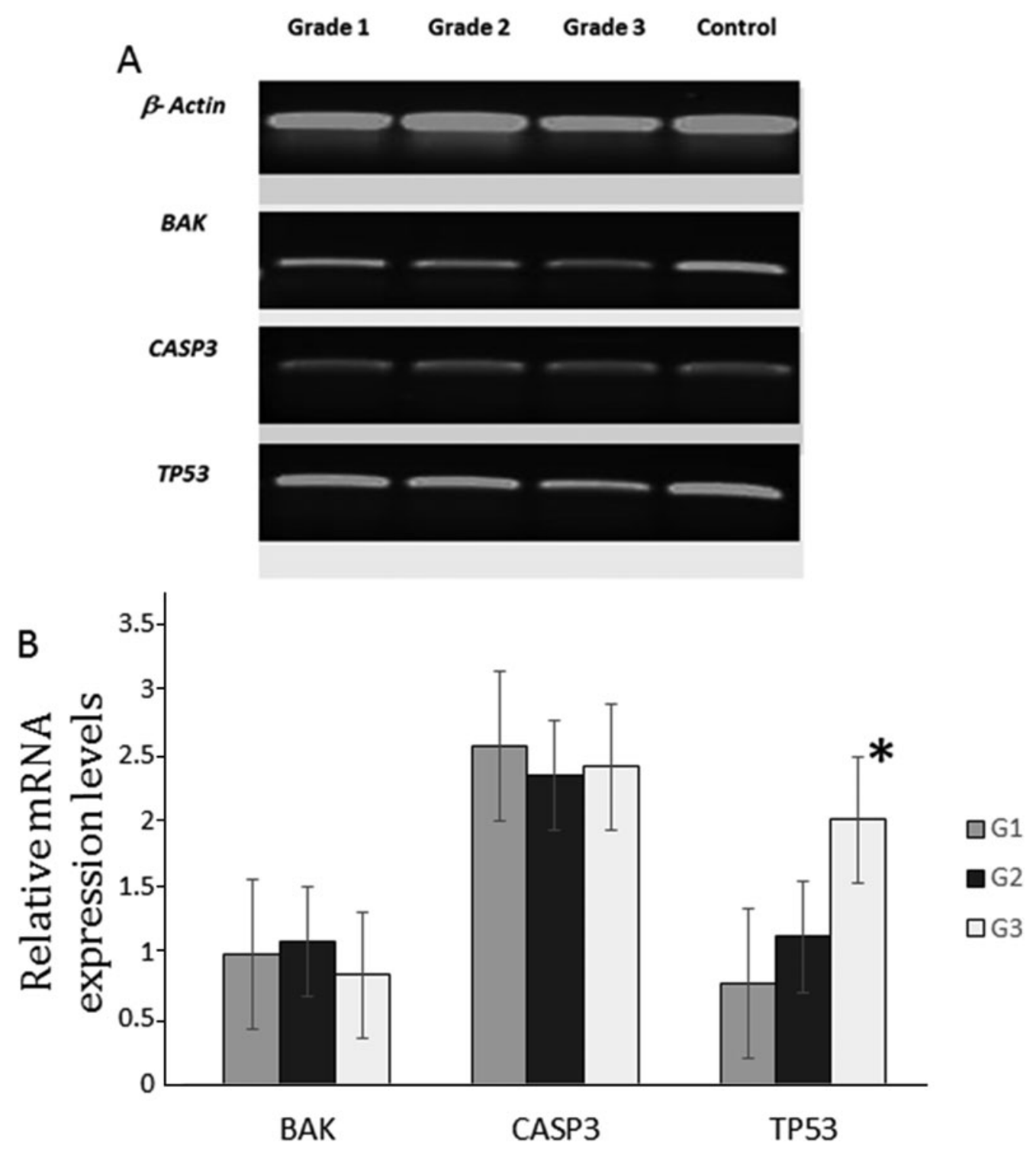

Figure $4(A)$ Reverse-transcription PCR of apoptosis-associated genes in lissamine B stained oocytes. Relative gene expression levels of lissamine B stained porcine oocytes. (B) The mRNA levels of BAK, Caspase 3 and TP53 were analysed in porcine oocytes. Results are displayed as fold changes in different grades of lissamine B stained oocytes relative to each other. Significant difference is marked with an asterisk $(* P<0.05)$.

TUNEL assay findings and the poorer developmental parameters of this grade. Studies in humans and mice have revealed a clear relationship between in vitro culture related stress and TP53 expression in embryos (Chandrakanthan et al., 2006). In mice, genetic inactivation of $M d m 2$, a negative regulator of p53, results in early embryonic lethality (Jones et al., 1995) that can be reversed by deletion of Trp53 (Luna et al., 1995), demonstrating that the p53 response pathway plays a direct role in embryonic loss.

It was expected that $B A K$ and $C A S P 3$ expression would also be greater in the lowest quality COCs, but this was not the case. BAK and CASP 3 are members of two important regulatory families involved in apoptosis. $B A K$ is a pro-apoptotic member of the Bcl2 family whose cytoplasmic elevation is sufficient to cause induction of oocyte apoptosis (Morita \& Tilly, 1999). The lack of any clear correlation between the RNA level of these genes and COC grade, despite evident DNA damage, could be due to a variety of reasons. One is that there is abundant maternal CASP3 mRNA in the oocytes (Weil et al., 1996), and this may mask any differential expression in the cumulus cells of different grades. Another is that regulation of caspase 3 activity is known to occur at the protein level, by modification of an inactive proenzyme. In which case direct immunocytological detection of the active form of caspase- 3 may be a more reliable measure. It is 
also known that caspase cleavage and DNA fragmentation do not take place simultaneously (Yuana et al., 2005). However, our findings are also consistent with similar observations in bovine embryos treated with the apoptosis inducer staurosporine, which showed no difference in the expression of several apoptosisrelated genes including CASP3 and other Bcl family genes (Vandaele et al., 2008).

Cumulus cells play a critical role in oocyte maturation and fertilization by releasing and mediating signals to oocytes (Vandaele et al., 2008), but the relationship between cumulus cell apoptosis and the development potential of the oocyte is unclear. There are in fact contradictory reports in various species as to whether definitive apoptosis actually takes place in COCs (Tanghe et al., 2002). For example, some studies have shown that human and bovine cumulus cells undergo apoptosis (Lee et al., 2001, Mikkelsen et al., 2001; Yuana et al., 2005), While others report the absence of apoptosis in cumulus cells of rats (Zeuner et al., 2003), pigs (Szoltys et al., 2000), and cattle (Manabe et al., 1996).

The simplicity and non-invasive nature of LB staining makes it straightforward to adopt as a quality control test for embryological labs. LB staining can give valuable information about the quality of oocytes in terms of maturational ability, developmental potential and extent of DNA damage. Further studies are clearly required to assess any long-term effects of LB on embryo survival and fetal health.

\section{Acknowledgements}

We would like to thank Steffen Löbnitz for help collecting samples. This work was financially supported by grant 16EX1024B; 'Platform Advanced Preclinical Animal Models' from the German Federal Ministry of Education and Research (Bundesministerium für Bildung und Forschung) as part of the $\mathrm{m}^{4}$ cluster initiative Personalized Medicine and Targeted Therapies. RD was supported by a scholarship from the German Academic Exchange Service (Deutscher Akademischer Austausch Dienst). The authors are members of COST Action BM1308 'Sharing Advances on Large Animal Models' (SALAAM).

\section{References}

Abeydeera, L.R. (2002). In vitro production of embryos in swine. Theriogenology 57, 256-73.

Abeydeera, L.R. \& Day, B.N. (1997). Fertilization and subsequent development of in vitro pig oocytes inseminated in a modified tris-buffered medium with frozen-thawed ejaculated spermatozoa. Biol. Reprod. 57, 729-34.

Akshey, Y.S., Malakar, D., De, A.K., Jena, M.K., Sahu, S. \& Dutta, R. (2011). Study of the efficiency of chemically assisted enucleation method for handmade cloning in goat (Capra hircus). Reprod. Domest. Anim. 46, 699704.

Assou, S., Haouzi, D., De Vos, J. \& Hamamah, S. (2010). Human cumulus cells as biomarkers for embryo and pregnancy outcomes. Mol. Hum. Reprod. 16, 531-8.

Brantom, P.G., Creasy, D.M. \& Gaunt, I.F. (1987). Long-term toxicity study of green $\mathrm{S}$ in mice. Food Chem. Toxicol. 25 , 977-83.

Chandrakanthan, V., Li, A., Chami, O. \& O'Neill, C. (2006). Effects of in vitro fertilization and embryo culture on TRP53 and Bax expression in B6 mouse embryos. Reprod. Biol. Endocrinol. 4, 61.

Cheng, W.T.K., Polge, C. \& Moor, R.M. (1986). In vitro fertilization of pig and sheep oocytes. Theriogenology 25, 146 (abstract).

Cheng, E., Chen, S., Lee, T.H., Pai, Y.P., Huang, L.S., Huang, C.C. \& Lee, M.S. (2013). Evaluation of telomere length in cumulus cells as a potential biomarker of oocyte and embryo quality. Hum. Reprod. 28, 929-36.

Clode, S.A. (1987). Teratogenicity and embryo toxicity study of green $S$ in rats. Food Chem. Toxicol. 25, 995-7.

Corn, C.M., Hauser-Kronberger, C., Moser, M., Tews, G. \& Ebner, T. (2005). Predictive value of cumulus cell apoptosis with regard to blastocyst development of corresponding gametes. Fertil. Steril. 84, 627-33.

Coticchio, G., Sereni, E., Serrao, L., Mazzone, S., Iadarola, I. \& Borini, A. (2004). What criteria for the definition of oocyte quality? New York Acad. Sci. 1034, 132-44.

Davachi Dadashpour, N., Kohram, H. \& Zainoaldini, S. (2012). Cumulus cell layers as a critical factor in meiotic competence and cumulus expansion of ovine oocytes. Small Rum. Res. 10, 237-42.

Flisikowska, T., Kind, A. \& Schnieke, A. (2013). The new pig on the block: modelling cancer in pigs. Transgenic Res. 22, 673-80.

Galeati, G., Modina, S., Lauria, A. \& Mattioli, M. (1991). Follicle somatic cells influence pig oocyte penetrability and cortical granule distribution. Mol. Reprod. Dev. 29, 406.

Gandhi, A., Lane, M., Gardner, D. \& Krisher, R. (2001). Substrate utilization in porcine embryos cultured in NCSU23 and G1.2/G2.2 sequential culture media. Mol. Reprod. Dev. 58, 269-75.

Garg, S., Dutta, R., Malakar, D., Jena, M.K., Kumar, D., Sahu, S. \& Prakash, B. (2012). Cardiomyocytes rhythmically beating generated from goat embryonic stem cell. Theriogenology 77, 829-39.

Grupen, C.G. (2014). The evolution of porcine embryo in vitro production. Theriogenology 81, 24-37.

Hamrah, P., Alipour, F., Jiang, S., Sohn, J.H. \& Foulks, G.N. (2011). Optimizing evaluation of lissamine green parameters for ocular surface staining. Eye 25, 1429-34.

Hendriksen, P.J., Vos, P.L., Steenweg, W.N.M., Bevers, M.M. \& Dielemans, S.J. (2000). Bovine follicular development and its effect on the in vitro competence of oocytes. Theriogenology 53, 11-20.

Hyttel, P., Fair, T., Callesen, H. \& Greve, T. (1997). Oocyte growth, capacitation and final maturation in cattle. Theriogenology 47, 23-32. 
Jones, S.N., Roe, A.E., Donehower, L.A. \& Bradley, A. (1995). Rescue of embryonic lethality in Mdm2-deficient mice by absence of p53. Nature 378, 206-8.

Kim, J. (2000). The use of vital dyes in corneal disease. Curr. Opin. Ophthalmol. 11, 241-7.

Kim, J. \& Foulks, G.N. (1999). Evaluation of the effect of lissamine green and rose Bengal on human corneal epithelial cells. Cornea 18, 328-32.

Lee, K.S., Joo, B.S., Na, Y.J., Yoon, M.S., Choi, O.H. \& Kim, W.W. (2001). Cumulus cells apoptosis as an indicator to predict the quality of oocytes and the outcome of IVF-ET. J. Assist. Reprod. Genet. 18, 490-8.

Livak, K.J. \& Schmittgen, T.D. (2001). Analysis of relative gene expression data using real-time quantitative PCR and the $2^{-\Delta \Delta} C_{\mathrm{T}}$ method. Methods 25, 402-8.

Luna, R.M.D., Wagner, D.S. \& Lozano, G. (1995). Rescue of early embryonic lethality in Mdm2-deficient mice by deletion of P53. Nature 378, 203-6.

Manabe, N., Imai, Y., Ohno, H., Takahagi, Y., Sugimoto, M. \& Miyamoto, H. (1996). Apoptosis occurs in granulosa cells but not cumulus cells in the atretic antral follicles in pig ovaries. Experientia 52, 647-51.

McElroy, S.L., Byrne, J.A., Chavez, S.L., Behr, B., Hsueh, A.J., Westphal, L.M. \& Pera Reijo, R.A. (2010). Parthenogenetic blastocyst derived from cumulus-free in vitro matured human oocytes. PLoS One 5, e10979.

Meyer, M., Martin, A.H., Wurst, W. \& Kühn, R.R. (2010). Gene targeting by homologous recombination in mouse zygotes mediated by zinc-finger nucleases. Proc. Natl. Acad. Sci. 107, 15022-6.

Mikkelsen, A.L., Host, E. \& Lindenberg, S. (2001). Incidence of apoptosis in granulosa cells from immature human follicles. Reproduction 122, 481-6.

Miyano, T. \& Manabe, N. (2007). Oocyte growth and acquisition of meiotic competence. Soc. Reprod. Fert. 63, 531-8.

Moorhouse, S.R., Creasy, D.M. \& Gaunt, I.F. (1987). Threegeneration toxicity study of rats ingesting green $S$ in the diet. Food Chem. Toxicol. 25, 985-93.

Morita, Y. \& Tilly, J.L. (1999). Oocyte apoptosis: like sand through an hourglass. Dev. Biol. 213, 1-17.

Nakai, M., Kashiwazaski, N., Takizawa, A., Hayashi, Y., Nakatsukasa, E., Fuchimoto, D., Noguchi, J., Kaneko, H. Shino, M. \& Kikuchi, K. (2003). Viable piglets generated from porcine oocyte matured in vitro and fertilized by intracytoplasmic sperm head injection. Biol. Reprod. 68, 1003-8.

Prates, E.G., Nunes, J.T. \& Pereira, R.M. (2014). A role of lipid metabolism during cumulus-oocyte complex maturation: impact of lipid modulators to improve embryo production. Med. Inflam. 11, 11.

Qian, Y., Shi, W., Ding, J., Sha, J. \& Fan, B. (2003). Predictive value of the area of expanded cumulus mass on development of porcine oocytes matured and fertilized in vitro. J. Reprod. Dev. 49, 167-74.

Rougier, N. \& Werb, Z. (2001). Minireview, Parthenogenesis in mammals. Mol. Reprod. Dev. 59, 468-74.
Ruppert-Lingham, C.J., Paynter, S.J., Godfrey, J., Fuller, B.J. \& Shaw, R.W. (2006). Membrane integrity and development of immature murine cumulus-oocyte complexes following slow cooling to $-60^{\circ} \mathrm{C}$ : the effect of immediate rewarming, plunging into LN2 and two-controlled-ratestage cooling. Cryobiology 52, 219-27.

Sirard, M.A., Richard, F., Blondin, P. \& Robert, C. (2006). Contribution of the oocyte to embryo quality. Theriogenology 65, 126-36.

Sjunnesson, Y.C.B., Morrell, J.M. \& González, R. (2013). Single layer centrifugation-selected boar spermatozoa are capable of fertilization in vitro. Acta Vet. Scand. 55, 20.

Szoltys, M., Tabarowski, Z. \& Pawlik, A. (2000). Apoptosis of postovulatory cumulus granulosa cells of the rat. Anat. Embryol. Berl. 202, 523-9.

Tanghe, S., Van Soom, A., Nauwynck, H., Coryn, M., de Kruif, A. (2002). Minireview: functions of the cumulus oophorus during oocyte maturation, ovulation, and fertilization. Mol. Reprod. Dev. 61, 414-24.

Tong, G.Q., Heng, B.C., Chen, N.Q., Yip, W.Y. \& Ng, S.C. (2004). Effects of elevated temperature in vivo on the maturational and developmental competence of porcine germinal vesicle stage oocytes. J. Anim. Sci. 82, 3175-80.

Uchikura, K., Nagano, M. \& Hishinuma, M. (2011). Prediction of maturational competence of feline oocytes using supravital staining of cumulus cells by propidium iodide. Zygote 20, 333-7.

Van Blerkom, J. (1996). The influence of intrinsic and extrinsic factors on the developmental potential and chromosomal normality of the human oocyte. J. Soc. Gynecol. Invest. 3, 3-10.

Vandaele, L., Goossens, K., Peelman, L. \& Van Soom, A. (2008). mRNA expression of Bcl-2, Bax, caspase-3 and 7 cannot be used as a marker for apoptosis in bovine blastocysts. Anim. Reprod. Sci. 106(1-2), 168-73.

Wang, W., Sun, Q., Hosoe, M., Shioya, Y. \& Day, B.B. (1997). Quantified analysis of cortical granule distribution and exocytosis of porcine oocytes during meiotic maturation and activation. Biol. Reprod. 56, 1376-82.

Weil, M., Jacobson, M.D., Coles, H.S.R, Davies, T.J., Gardner, R.L., Raff, K.D. \& Raff, M.C. (1996). Constitutive expression of the machinery for programmed cell death. J. Cell Biol. 133, 1053-9.

Yuana, Y.Q., Van Sooma, A., Leroya, J.L.M.R., Dewulfa, J., Van Zeverenb, A., de Kruifa, A. \& Peelman, L.J. (2005). Apoptosis in cumulus cells, but not in oocytes, may influence bovine embryonic developmental competence. Theriogenology 63, 2147-63.

Yuge, M.M. (2003). Effects of cooling ovaries before oocyte aspiration on meiotic competence of porcine oocytes and of exposing in vitro matured oocytes to ambient temperature on in vitro fertilization and development of the oocytes. Cryobiology 47, 102-8.

Zeuner, A., Muller, K., Reguszynski, K. \& Jewgenow, K. (2003). Apoptosis within bovine follicular cells and its effect on oocyte development during in vitro maturation. Theriogenology 59, 1421-33. 